\title{
Effect of condensed tannins from Leucaena leucocephala on rumen fermentation, methane production and population of rumen protozoa in heifers fed low-quality forage
}

\author{
Angel T. Piñeiro-Vázquez ${ }^{1,2, *}$, Jorge R. Canul-Solis ${ }^{1}$, Guillermo 0. Jiménez-Ferrer ${ }^{3}$, José A. Alayón-Gamboa ${ }^{4}$, \\ Alfonso J. Chay-Canul' ${ }^{5}$, Armin J. Ayala-Burgos ${ }^{1}$, Carlos F. Aguilar-Pérez ${ }^{1}$, and Juan C. Ku-Vera ${ }^{1}$
}

\begin{abstract}
* Corresponding Author: Angel T. Piñeiro-Vázquez Tel: +52-9991013338, Fax: +52-9991013338, E-mail: pineiroiamc@gmail.com

${ }^{1}$ Facultad de Medicina Veterinaria y Zootecnia, Universidad Autónoma de Yucatán. C.P. 97300 Mérida, Yucatán, México

2 Instituto Tecnológico de Conkal, Avenida Tecnológico s/n C.P. 97345 Conkal, Yucatán, México

${ }^{3}$ El Colegio de la Frontera Sur (ECOSUR), Ganadería y Ambiente, Carretera Panamericana y Periférico Sur s/n, Barrio María Auxiliadora, San Cristóbal de Las Casas, Chiapas 29290, México

${ }^{4}$ El Colegio de la Frontera Sur, Unidad Campeche, México. Av. Rancho Polígono 2-A, Ciudad Industrial Lerma, C.P.24500, Campeche, México

${ }^{5}$ División Académica de Ciencias Agropecuarias, Universidad Juárez Autónoma de Tabasco, Carretera Villahermosa-Teapa, km 25, R/a. La Huasteca 2a. Sección, C.P. 86280 Villahermosa, Tabasco, México
\end{abstract}

ORCID

Angel T. Piñeiro-Vázquez

https://orcid.org/0000-0002-8400-4046

Submitted Mar 15, 2017; Revised May 31, 2017 ; Accepted Oct 22, 2017
Objective: The aim of the experiment was to assess the effect of increasing amounts of Leucaena leucocephala forage on dry matter intake (DMI), organic matter intake (OMI), enteric methane production, rumen fermentation pattern and protozoa population in cattle fed Pennisetum purpureum and housed in respiration chambers.

Methods: Five crossbred heifers (Bos taurus $\times$ Bos indicus) (BW: $295 \pm 6 \mathrm{~kg}$ ) were fed chopped P. purpureum grass and increasing levels of L. leucocephala $(0 \%, 20 \%, 40 \%, 60 \%$, and $80 \%$ of dry matter $[\mathrm{DM}])$ in a $5 \times 5$ Latin square design.

Results: The voluntary intake and methane production were measured for $23 \mathrm{~h}$ per day in respiration chambers; molar proportions of volatile fatty acids (VFAs) were determined at $6 \mathrm{~h}$ postprandial period. Molar concentration of VFAs in rumen liquor were similar ( $p>0.05)$ between treatments. However, methane production decreased linearly $(\mathrm{p}<0.005)$, recording a maximum reduction of up to $\sim 61 \%$ with $80 \%$ of DM incorporation of L. leucocephala in the ration and no changes $(\mathrm{p}>0.05)$ in rumen protozoa population were found.

Conclusion: Inclusion of $80 \%$ of L. leucocephala in the diet of heifers fed low-quality tropical forages has the capacity to reduce up to $61.3 \%$ enteric methane emission without affecting DMI, OMI, and protozoa population in rumen liquor.

Keywords: Methane; Crossbred Heifers; Volatile Fatty Acids; Forages; Respiration Chambers

\section{INTRODUCTION}

Methane $\left(\mathrm{CH}_{4}\right)$ gas is a byproduct of anaerobic fermentation of carbohydrates in the rumen. It is considered a greenhouse gas with a global warming potential twenty-three times greater than that of $\mathrm{CO}_{2}[1]$ and every year 80 million tons are generated from anthropogenic activities. It has been estimated that enteric methane contributes $39.1 \%$ of greenhouse gas emissions generated by the livestock sector [2]. Additionally, $\mathrm{CH}_{4}$ emissions represent an energy loss which ranges from $2 \%$ to $12 \%$ of the gross energy consumed by ruminants [3].

In tropical regions, ruminants are usually fed low-quality forages which are characterized by their low concentration of crude protein $(\mathrm{CP})$ and digestible energy, and their high content of neutral detergent fiber (NDF) and lignin, which induces a higher methane convention rate value [4] decreasing the efficiency of energy utilization [5]. Nonetheless, feeding ruminants with legumes favors a lower $\mathrm{CH}_{4}$ production [6].

In the tropical regions, there is a large diversity of legume species which contain secondary metabolites such as condensed tannins (CT), which decreases the protozoa population, methanogenic archaea [7], and the synthesis of enteric $\mathrm{CH}_{4}$ [8,9]. Leucaena leucocephala (L. leucocephala) is one of the main tropical shrub species which contains CT with potential 
to reduce $\mathrm{CH}_{4}$ emissions [10], improve $\mathrm{CP}$ digestibility [11], $\mathrm{N}$ retention $[8,9]$ and improve the efficiency of energy intake by ruminants [12]. Harrison et al [13] have recently reported higher levels of productivity with cattle fed leucaena in Australia as well as lower enteric $\mathrm{CH}_{4}$ emissions to the atmosphere.

The aim of the work hereby described was to assess the effect of supplying increasing concentrations of CT from $L$. leucocephala in the ration on feed intake, molar proportions of volatile fatty acids (VFAs), changes in rumen protozoa population and enteric $\mathrm{CH}_{4}$ emissions by heifers fed a basal ration of tropical grass.

\section{MATERIALS AND METHODS}

\section{Animal care}

The animals were treated in accordance with guidelines and regulations for animal experimentation of the Faculty of Veterinary Medicine and Animal Science (FMVZ), University of Yucatan, Merida, Mexico.

\section{Location}

The experiment was carried out at the FMVZ, University of Yucatan in Merida, Mexico. Climate in the region is warm with an average temperature of $26.8^{\circ} \mathrm{C}$ and average rainfall of 984.4 mm per year [14].

\section{Experimental animals}

Five crossbred (Bos taurus $\times$ Bos indicus) heifers with an average body weight (BW) of $295 \pm 6.8 \mathrm{~kg}$ were housed in metabolic crates in a roofed building with concrete floor without walls. Before the experiment heifers were internally dewormed with Ivermectin (AGROVET, S.A de C.V. Mexico, Federal District, Mexico) (1\%; $1 \mathrm{~mL} / 50 \mathrm{~kg} \mathrm{BW})$ and injected intramuscularly with $\mathrm{ADE}$ vitamins ( $1 \mathrm{~mL} / 10 \mathrm{~kg} \mathrm{BW})$.

\section{Experimental design and treatments}

A $5 \times 5$ Latin square design [15] was used; each period lasted 19 days ( 13 days for adaptation to management and rations, and six days for measurements of response variables). During the adaptation period (13 days), the animals remained outside the chambers and only during the measurement period (6 days) the intake, digestibility and enteric methane production were measured. Prior to the experiment, animals were adapted to enter the respiration chambers for a period of $\sim 3$ weeks to reduce the effect of stress on voluntary intake of dry matter (DM) and behavior in and out of the chambers. Basal ration consisted of fresh forage of Taiwan (Pennisetum purpureum [P. purpureum]) grass and increasing levels of chopped forage of $L$. leucocephala as a replacement for the $P$. purpureum forage which was homogeneously mixed (Forage-legume) to avoid selection. The chemical composition of the forages is shown in Table 1. Experimental treatments were increasing levels of
Table 1. Chemical composition of the forages ( $\mathrm{g} / \mathrm{kg} \mathrm{DM})$

\begin{tabular}{|c|c|c|}
\hline Item & $\begin{array}{l}\text { Pennisetum } \\
\text { purpureum }\end{array}$ & $\begin{array}{c}\text { Leucaena } \\
\text { leucocephala }\end{array}$ \\
\hline Organic matter & 930.32 & 940.5 \\
\hline Crude protein & 60.64 & 160.29 \\
\hline NDF & 670.62 & 580.85 \\
\hline ADF & 410.99 & 420.01 \\
\hline Lignin & 70.24 & 160.0 \\
\hline \multicolumn{3}{|c|}{ Secondary metabolites (g/kg DM) } \\
\hline Total phenols ${ }^{1)}$ & 0 & 7.7 \\
\hline Condensed tannins ${ }^{2)}$ & 0 & 21.0 \\
\hline
\end{tabular}

DM, dry matter; NDF, neutral detergent fiber; ADF, acid detergent fiber.

1) Expressed as g tannic acid eq/kg DM.

${ }^{2)}$ Expressed as g leucocyanidin eq $/ \mathrm{kg}$ DM.

L. leucocephala $(0 \%, 20 \%, 40 \%, 60 \%$, and $80 \%$ of DM) in the ration. Additionally, heifers were supplemented with a commercial mineral mixture Fogysal Cattle (FOGYSA S.A de C.V. Merida, Yucatan, Mexico) (250 g/heifers/d).

\section{Response variables}

Determination of rumen $\mathrm{pH}$ and molar proportions of volatile fatty acid: Samples of rumen liquor were taken by an esophageal tube according to Ramos-Morales et al [16]. Rumen liquor was obtained during six days before measurements in each period, six hours postprandial according to recommendations by Hales et al [17] and Bathha et al [18] in order to analyze rumen $\mathrm{pH}$ and pattern of VFA's in the rumen. Samples of rumen liquor were filtered through double layers of cheesecloth to retain large particles. Rumen $\mathrm{pH}$ was determined immediately after taking the sample with a portable potentiometer (HANNA Instruments, Woonsocket, RI, USA), previously calibrated with buffers at $\mathrm{pH}$ 's 4,7 and 10. For the determination of molar proportions of VFA's in rumen liquor, $4 \mathrm{~mL}$ samples were taken and added $1 \mathrm{~mL}$ of a deproteinizing solution consisting of metaphosphoric and 3-methilvaleric acids. For VFA analysis, the technique proposed by Ryan [19] was employed using a gas chromatograph (Hewlett-Packard, 5890 series III), equipped with a flame ionization detector and a column HP-FFAP measuring $30 \mathrm{~m} \times 0.53 \mathrm{~mm}$, temperature of the injector and the detector was in both cases $200^{\circ} \mathrm{C}$.

\section{Measurement of enteric $\mathrm{CH}_{4}$}

Measurement of $\mathrm{CH}_{4}$ was carried out while heifers were housed in respiration chambers [20], with dimensions $2.10 \mathrm{~m} \times 1.60$ $\mathrm{m} \times 3.10 \mathrm{~m}$ (height, width and length, respectively) and a total internal volume of $9.38 \mathrm{~m}^{3}$. Mass flow generators (Sable Systems International, Las Vegas, NV, USA) pulled out the air from the chamber at a rate of $500 \mathrm{~L} / \mathrm{min}$ creating a negative pressure of $475 \mathrm{~Pa}$ inside the chamber relative to the outside environment.

Measurement of $\mathrm{CH}_{4}$ in air samples was carried out with 
an infrared analyzer (MA-10, Sable Systems International, USA). High purity $\mathrm{CH}_{4}$ gas (99.9999\% $\mathrm{CH}_{4}$; Praxair, Mexico) was released from a small cylinder into the chambers and the recovery rate was assessed to be $100.2 \%$ which is comparable to recovery rates obtained in other laboratories [21]. The methane analyzer was zeroed by infusing pure $\mathrm{N}_{2}$ and the linearity $\left(r^{2}=0.9999\right)$ of the analyzer response was assessed by infusing increasing concentrations of methane $(1,000 ; 2,500 ; 5,000$; $7,500 \mathrm{ppm}$ ) diluted in $\mathrm{N}_{2}$ before each run. Heifers were kept inside the respiration chambers at a temperature of $23^{\circ} \mathrm{C}$ and relative humidity of $55 \%$. Fresh water was available at all times from an automatic drinking bowl and a small fan mixed the air inside the chambers. Methane measurements were carried out during three consecutive days for $23 \mathrm{~h}$ continuously during the measurement period of the response variables, inside the respiration chambers intake and digestibility were also measured $[20,4]$. Data obtained were adjusted to $24 \mathrm{~h}$ runs with ExpeData software (Sable Systems International, USA) and converted to liters of methane produced per day.

\section{Voluntary intake}

Heifers were fed ad libitum allowing a refusal of at least 15\% of the dry matter offered the previous day. Feed refusals were weighed at $0900 \mathrm{~h}$ the following day. Voluntary intake was determined by the difference between the amount offered and refused. Feed offered covered an estimated intake of $7.0 \mathrm{~kg}$ $\mathrm{DM} / \mathrm{d}$.

\section{Rumen protozoa population}

Protozoa in samples of rumen liquor were counted according to the procedures described by Rosales [22]. One $\mathrm{mL}$ of rumen liquor was mixed with $1 \mathrm{~mL}$ of methylgreen formalin saline solution ( $35 \mathrm{~mL} / \mathrm{L}$ formaldehyde, $0.14 \mathrm{mM} \mathrm{NaCl}, 0.92 \mathrm{mM}$ methylgreen) and centrifuged at 2,000 rpm for $20 \mathrm{~min}$. Then, an aliquot was taken and introduced to a modified FuschRosenthal chamber (Electron Microscopy Science, Hatfield, PA, USA) (IVD 98/79 CE) and observed under the microscope (Mikon-YS100) (Nikon Instruments Inc, Melville, NY, USA) at $40 \times$. Number of ciliate protozoa was reported as $\log 10$ from total number+1 per $\mathrm{mL}$ of rumen liquor. Number of protozoa was estimated with the following formulae [23]: Number of cells per $\mathrm{mL}^{-1}=[(\mathrm{n} 1+\mathrm{n} 2+\mathrm{n} 3+\mathrm{n} 4+\mathrm{n} 5) / 5] / 0.022 \mathrm{~mm}^{3} \times 10^{3} \times \mathrm{d}$. where: $\mathrm{n} 1$...n5: number of protozoa per large square and $\mathrm{d}$ $=$ dilution factor. Classification of protozoa was carried out according to Ogimoto and Imai [24].

\section{Chemical analysis}

Dry matter was determined in a forced air oven at $55^{\circ} \mathrm{C}$ for 48 h (constant weight) (\#7.007) [25]. Nitrogen ( $\mathrm{CP}=\mathrm{N} \times 6.25)$ determinations were carried out with a LECCO CN-2000 series 3740 instrument (LECCO, Corporation, Saint Joseph, MI, USA) (\#2.057) [25]. Organic matter was assessed by in- cineration in muffle furnace at $550^{\circ} \mathrm{C}$ for $6 \mathrm{~h}$ (AOAC Method \#923.03) and the content of NDF and acid detergent fiber (ADF) were determined using the methods described by Van Soest et al [26]. Concentration of CT in forage samples was performed by the HCL-butanol method described by Makkar [27].

\section{Statistical analysis}

Data on voluntary intake, apparent digestibility, nitrogen balance, protozoa population and $\mathrm{CH} 4$ production were subjected to analysis of variance for a $5 \times 5$ Latin square design [15] using the procedure PROC ANOVA from SAS (SAS Inst. Inc., Cary, NC, USA) with the model $Y_{i \mathrm{ijk}}=\mu+\mathrm{P}_{\mathrm{i}}+\mathrm{A}_{\mathrm{j}}+\mathrm{T}_{\mathrm{k}}+\mathrm{e}_{\mathrm{ijk}}$, where $\mathrm{Y}_{\mathrm{ijk}}$ is the dependent variable, $\mu$ is the general mean, $P_{i}$ is the effect of period, $A_{j}$ is the effect of animal, $T_{k}$ is the effect of treatment, and $\mathrm{e}_{\mathrm{i} \mathrm{k} \mathrm{k}}$ is the residual error. Statistical differences were declared significant at $\mathrm{p} \leq 0.05$. Additionally, surface response analysis was carried out to assess the linear, quadratic or cubic effects [28] of the response to treatments $(0 \%, 20 \%, 40 \%, 60 \%$, and $80 \%$ of $L$. leucocephala in the ration).

\section{RESULTS}

\section{Voluntary intake}

Dry matter intake (DMI, $\mathrm{kg} / \mathrm{d}$ and $\mathrm{g} / \mathrm{kg}^{0.75}$ ) was similar among treatments with different levels of $L$. leucocephala forage, reporting an average of $7.0(\mathrm{~kg} / \mathrm{d})$ and $98.7\left(\mathrm{~g} / \mathrm{kg}^{0.75}\right)$, respectively ( $p>0.05)$. Organic matter intake (OMI) followed the same trend as DMI (Table 2). However, crude protein intake (CPI) increased linearly as the level of incorporation of L. leucocephala in the ration was augmented $(\mathrm{p}<0.0001)$.

\section{Enteric methane production}

The average of methane production in this study was $20.1 \mathrm{~L} / \mathrm{kg}$ of DMI with the control treatment and as L. leucocephala increased in the diet there was a reduced $\mathrm{CH}_{4}$ production; with incorporation of $80 \%$ of $L$. leucocephala in the ration methane production reduced by $61.6 \%$ respect to $0 \%$ of legume (linear reduction $\mathrm{p}=0.0005)$. Also, methane emissions expressed as L CH4/d, kg of DM, OM, NDF, ADF intake, kg of digestibility dry matter, and organic matter digestibility (OMD), neutral detergent fiber digestibility (NDFD), an acid detergent fiber digestibility $(\mathrm{ADFD})$ was linearly reduced $(\mathrm{p}<0.01)$ as the percentage incorporation of $L$. leucocephala in the ration was increased (Table 3).

\section{$\mathrm{pH}, \mathrm{NH}_{3}-\mathrm{N}$, and molar proportions of volatile fatty} acid in the rumen

No differences were observed in rumen $\mathrm{pH}$ as the inclusion of $L$. leucocephala in the ration of cattle was increased ( $p>0.05)$. Although rumen $\mathrm{NH}_{3}-\mathrm{N}$ was different between treatments and linearly increased as the level of the foliage of the legume 
Table 2. Intake and apparent digestibility in crossbred heifers fed Pennisetum purpureum grass and increasing levels of Leucaena leucocephala

\begin{tabular}{|c|c|c|c|c|c|c|c|}
\hline \multirow{2}{*}{ Items } & \multicolumn{5}{|c|}{ Percentage of $L$. leucocephala supplemented (\% of DM) } & \multirow{2}{*}{ SE } & \multirow{2}{*}{$\begin{array}{c}\text { Contrast } \\
\mathrm{L}\end{array}$} \\
\hline & 0 & 20 & 40 & 60 & 80 & & \\
\hline BW (kg) & 293.80 & 298.80 & 289.20 & 298.20 & 295.40 & 6.81 & \\
\hline \multicolumn{8}{|l|}{ Intake } \\
\hline $\mathrm{DM}(\mathrm{kg} / \mathrm{d})$ & 7.03 & 7.15 & 7.07 & 7.00 & 7.00 & 0.60 & ns \\
\hline $\mathrm{OM}(\mathrm{kg} / \mathrm{d})$ & 6.54 & 6.70 & 6.62 & 6.53 & 6.50 & 0.55 & ns \\
\hline$C P(\mathrm{~kg} / \mathrm{d})$ & 0.50 & 0.70 & 0.82 & 0.93 & 1.22 & 0.10 & ** \\
\hline $\operatorname{NDF}(\mathrm{kg} / \mathrm{d})$ & 4.63 & 4.50 & 4.30 & 4.10 & 3.83 & 0.40 & ns \\
\hline $\operatorname{ADF}(\mathrm{kg} / \mathrm{d})$ & 2.85 & 2.81 & 2.77 & 2.67 & 2.50 & 0.25 & ns \\
\hline \multicolumn{8}{|c|}{ Digestible intake $(\mathrm{kg} / \mathrm{d})$} \\
\hline DDM & 3.90 & 3.71 & 3.46 & 3.46 & 3.40 & 0.54 & ns \\
\hline OMD & 3.72 & 3.54 & 3.32 & 3.29 & 3.21 & 0.52 & ns \\
\hline NDFD & 2.60 & 2.15 & 1.91 & 1.77 & 1.51 & 0.33 & * \\
\hline ADFD & 1.55 & 1.30 & 1.12 & 1.05 & 0.81 & 0.22 & * \\
\hline
\end{tabular}

DM, dry matter; SE, standard error; L, linear contrast; BW, body weight; OM, organic matter; CP, crude protein; NDF, neutral detergent fiber; ADF, acid detergent fiber; DDM: digestible dry matter; OMD: digestible organic matter; NDFD: digestible neutral detergent fiber; ADFD: digestible acid detergent fibre.

${ }^{*} p<0.05 ;{ }^{* *} p<0.01$; ns: non-significant $(p>0.05)$. No significant effects were found for the quadratic and cubic contrasts.

was increased $(\mathrm{p}<0.01)$. As from $80 \%$ of L. leucocephala (36 $\mathrm{mg} / \mathrm{dL}$ ) in the ration, rumen $\mathrm{NH}_{3}-\mathrm{N}$ was significantly increased (138\%) with respect to the treatment without incorporation of L. leucocephala $(15.3 \mathrm{mg} / \mathrm{dL})(\mathrm{p}<0.05)$ (Table 4$)$.

Molar proportions of acetic, propionic and butyric acids in rumen liquor were not affected ( $\mathrm{p}>0.05$ ) by the incorporation of $L$. leucocephala in the ration, registering averages of $53.8,12.9$, and $5.7 \mathrm{mmol} / \mathrm{L}$, respectively. When the molar proportion of acetic acid was expressed as percentage, a linear increase $(\mathrm{p}=0.037)$ was detected as the level of incorporation of $L$. leucocephala was increased. Conversely, the molar proportion of propionic acid maintained a linear reduction $(\mathrm{p}=0.032)$ as L. leucocephala was increased in the ratio $(\mathrm{p}<0.0002)$ (Table 4).

\section{Rumen protozoa population}

Total protozoa numbers, holotrichs, and entodiniomorph in the rumen of cattle were not affected at $6 \mathrm{~h}$ after intake of $L$. leucocephala forage $(\mathrm{p}>0.05)$ (Table 5).

\section{DISCUSSION}

\section{Voluntary intake}

Intake of tropical foliage that contains $\mathrm{CT}$ at moderate concentrations ( $3 \%$ to $6 \%$ of $\mathrm{DM}$ ) improves the nutrient intake of ruminant rations, particularly DM, OM, and CP [29]. In the present work, the incorporation of up to $80 \%$ of L. leucocephala equivalent to a supply of $16.4 \mathrm{~g} / \mathrm{kg}$ DMI of CT only had an influence on the greater CP intake $(\mathrm{kg} / \mathrm{d}, \mathrm{CPI} / \mathrm{kg}$ di-

Table 3. Methane $\left(\mathrm{CH}_{4}\right)$ production in crossbred heifers fed Pennisetum purpureum grass and increasing levels of Leucaena leucocephala

\begin{tabular}{|c|c|c|c|c|c|c|c|c|c|}
\hline \multirow{2}{*}{ Items } & \multicolumn{5}{|c|}{ Percent of L. leucocephala supplemented (\% of DM) } & \multirow{2}{*}{ SE } & \multicolumn{3}{|c|}{ Contrast } \\
\hline & 0 & 20 & 40 & 60 & 80 & & L & Q & C \\
\hline $\mathrm{BW}(\mathrm{kg})$ & 293.8 & 298.8 & 289.2 & 298.2 & 295.4 & 6.8 & & & \\
\hline \multicolumn{10}{|l|}{ Enteric methane } \\
\hline $\mathrm{LCH}_{4} / \mathrm{d}$ & 137.3 & 101.2 & 87.4 & 74.9 & 53.5 & 14.8 & ** & ns & ns \\
\hline $\mathrm{LCH}_{4} / \mathrm{kg}$ of DMl & 20.1 & 14.7 & 12.1 & 10.5 & 7.7 & 2.1 & ** & ns & ns \\
\hline $\mathrm{LCH}_{4} / \mathrm{kg}$ of $\mathrm{OMI}$ & 21.6 & 15.7 & 13.0 & 11.2 & 8.3 & 2.3 & ** & ns & ns \\
\hline $\mathrm{LCH}_{4} / \mathrm{kg}$ of NDFI & 30.4 & 23.3 & 20.0 & 17.9 & 14.3 & 3.4 & ** & ns & ns \\
\hline $\mathrm{LCH}_{4} / \mathrm{kg}$ of $\mathrm{ADFI}$ & 49.1 & 37.2 & 31.0 & 27.7 & 21.9 & 5.3 & ** & ** & ns \\
\hline \multicolumn{10}{|c|}{$\mathrm{L}$ of methane $/ \mathrm{kg}$ of digestible fractions intake } \\
\hline $\mathrm{LCH}_{4} / \mathrm{kg}$ of DDM & 37.7 & 30.3 & 25.8 & 22.7 & 17.3 & 5.1 & ** & ns & ns \\
\hline $\mathrm{LCH}_{4} / \mathrm{kg}$ of OMD & 39.6 & 31.6 & 26.9 & 23.9 & 18.5 & 5.4 & $* *$ & ns & ns \\
\hline $\mathrm{LCH}_{4} / \mathrm{kg}$ of NDFD & 56.5 & 52.4 & 47.6 & 48.7 & 49.2 & 11.5 & ns & ns & ns \\
\hline $\mathrm{LCH}_{4} / \mathrm{kg}$ of ADFD & 92.0 & 86.1 & 84.5 & 88.8 & 131.5 & 33.2 & ns & ns & ns \\
\hline
\end{tabular}

$\mathrm{DM}$, dry matter; SE, standard error; L, linear contrast; Q, quadratic contrast; C, cubic contrast; BW, body weight; DMI, dry matter intake; OMI, organic matter intake; NDFI, neutral detergent fiber intake; $A D F I$, acid detergent fiber intake; DDM, digestible dry matter; OMD, digestible organic matter; NDFD, digestible neutral detergent fiber; $A D F D$, digestible acid detergent fiber.

${ }^{*} p<0.05 ;{ }^{* *} p<0.01 ;$ ns, non-significant $(p>0.05)$. 
Table 4. Effects of $\mathrm{CT}$ on ruminal pH, N-NH , and volatile fatty acids (VFA's) in crossbred heifers fed Pennisetum purpureum grass and increasing levels of Leucaena leucocephala

\begin{tabular}{|c|c|c|c|c|c|c|c|c|c|}
\hline \multirow{2}{*}{ Items } & \multicolumn{5}{|c|}{ Percent of $L$. leucocephala supplemented (\% of DM) } & \multirow{2}{*}{ SE } & \multicolumn{3}{|c|}{ Contrast } \\
\hline & 0 & 20 & 40 & 60 & 80 & & $\mathbf{L}$ & Q & C \\
\hline Rumen $\mathrm{pH}$ & 6.8 & 6.9 & 6.7 & 6.8 & 6.8 & 0.10 & ns & ns & ns \\
\hline Rumen N-NH$H_{3}(\mathrm{mg} / \mathrm{dL})$ & 15.3 & 22.0 & 27.3 & 34.0 & 36.5 & 0.07 & ** & ns & ns \\
\hline \multicolumn{10}{|c|}{ Volatile fatty acids concentration (mmol/L) } \\
\hline Acetate & 52.6 & 54.8 & 53.4 & 52.1 & 54.4 & 5.31 & ns & ns & ns \\
\hline Propionate & 13.6 & 13.1 & 12.8 & 12.2 & 12.8 & 1.14 & ns & ns & ns \\
\hline Butyrate & 6.1 & 6.1 & 5.6 & 5.3 & 5.4 & 0.47 & ns & ns & ns \\
\hline Isobutyric & 0.4 & 0.36 & 0.4 & 0.37 & 0.3 & 0.04 & ns & ns & ns \\
\hline Valeric & 0.3 & 0.34 & 0.4 & 0.4 & 0.4 & 0.04 & * & ns & ns \\
\hline Isovaleric & 0.2 & 0.2 & 0.2 & 0.2 & 0.2 & 0.04 & ns & ns & ns \\
\hline TotalVFA & 73.5 & 75.0 & 72.9 & 70.7 & 73.8 & 6.90 & ns & ns & ns \\
\hline$A: P$ & 3.8 & 4.1 & 4.1 & 4.2 & 4.2 & 0.10 & * & ns & ns \\
\hline \multicolumn{10}{|c|}{ Molar proportions of VFA (\%) } \\
\hline Acetate & 71.4 & 72.9 & 73.1 & 73.5 & 73.5 & 0.67 & * & ns & ns \\
\hline Propionate & 18.6 & 17.6 & 17.7 & 17.4 & 17.5 & 0.33 & * & ns & ns \\
\hline Butyrate & 8.5 & 8.3 & 7.7 & 7.6 & 7.5 & 0.41 & ns & ns & ns \\
\hline Isobutyric & 0.5 & 0.5 & 0.5 & 0.5 & 0.5 & 0.05 & ns & ns & ns \\
\hline Valeric & 0.4 & 0.4 & 0.5 & 0.6 & 0.6 & 0.04 & ** & ns & ns \\
\hline Isovaleric & 0.3 & 0.3 & 0.3 & 0.3 & 0.3 & 0.06 & * & ns & ns \\
\hline
\end{tabular}

$\mathrm{CT}$, condensed tannins; $\mathrm{NH}_{3}$, ammonia; $\mathrm{DM}$, dry matter; SE, standard error; L, linear contrast; Q, quadratic contrast; C, cubic contrast; A:P, acetic:propionic relationship.

${ }^{*} p<0.05 ;{ }^{*} p<0.01$; ns, non-significant $(p>0.05)$.

gestibility organic matter intake [DOMI]) without affecting DMI, OMI, and acid detergent fiber intake (Table 2). Additionally, reduction in NDF intake might have been influenced by the small amount of NDF contained in the foliage of L. leucocephala $(580.8 \mathrm{~g} / \mathrm{kg} \mathrm{DM})$ and as the level of incorporation of tree foliage was increased, the amount of NDF was reduced [6]. These results differ from those of Delgado et al [30] when they included $27 \%$ of L. leucocephala in sheep rations and observed an increase in the DMI and OMI, similar to results reported by Wahyuni et al [11] who observed an increase in DMI when they included increasing levels of L. leucocephala, registering an increase of $30 \%$, when $60 \%$ leucaena was incorporated in the ration compared to a control treatment.

It has been pointed out that doses below $2 \% \mathrm{CT}$ do not affect DMI [31,32]. Grainger et al [33] found that 1.46\% CT in the ration of dairy cows did not affect DMI and Beauchemin et al [32] using $2 \%$ CT in cattle rations did not find an effect on nutrient intake. In this study, levels of up to $80 \%$ L. leuco- cephala only produces $1.64 \%$ of CT per $\mathrm{kg}$ DMI in the cattle ration, thus it is unlikely that this level influenced DM and OM intakes.

\section{Enteric methane production}

In this experiment, with heifers fed foliage of L. leucocephala, the methane production was lower $(11.5 \mathrm{~L} / \mathrm{kg}$ of DM) $[6,34,8]$ in respect to the heifers without inclusion of L. leucocephala $(20.1 \mathrm{~L} / \mathrm{kg}$ of DM) in the ration. In this context, $80 \%$ of L. leucocephala foliage in the ration, decreased by $\sim 61 \%$ the rumen methane production with respect to the control treatment, these results were similar to those obtained $[35,8,34]$.

In the present work, a linear reduction in ruminal methane production was observed as the level of foliage of L. leucocephala in the ration was increased (Table 3) and could be associated with CT content. Several studies have demonstrated that inclusion of CT using L. leucocephala, reduces ruminal methane production. Tan et al [36] under in vitro conditions

Table 5. Population of rumen protozoa ( $\log _{10}$ cells $/ \mathrm{mL}$ ) in crossbred heifers fed Pennisetum purpureum grass and increasing levels of Leucaena leucocephala

\begin{tabular}{|c|c|c|c|c|c|c|c|c|c|}
\hline \multirow{2}{*}{ Items } & \multicolumn{5}{|c|}{ Percent of L. leucocephala supplemented (\% of DM) } & \multirow{2}{*}{ SE } & \multicolumn{3}{|c|}{ Contrast } \\
\hline & 0 & 20 & 40 & 60 & 80 & & $\mathrm{~L}$ & Q & C \\
\hline \multicolumn{10}{|c|}{ Population of rumen protozoa } \\
\hline Holotrich $\left(\log _{10}\right)$ & 4.0 & 4.1 & 4.1 & 3.9 & 4.1 & 0.18 & ns & ns & ns \\
\hline Entodiniomorph $\left(\log _{10}\right)$ & 5.5 & 5.3 & 5.5 & 5.5 & 5.5 & 0.07 & ns & ns & ns \\
\hline Total protozoa $\left(\log _{10}\right)$ & 9.5 & 9.4 & 9.6 & 9.3 & 9.6 & 0.19 & ns & ns & ns \\
\hline
\end{tabular}

$\mathrm{DM}$, dry matter; $\mathrm{SE}$, standard error; L, linear contrast; $\mathrm{Q}$, quadratic contrast; $C$, cubic contrast.

${ }^{*} p<0.05 ;{ }^{* *} p<0.01 ;$ ns, non-significant ( $\left.p>0.05\right)$. 
found a linear reduction in $\mathrm{CH}_{4}$ production when they included $20 \%, 30 \%, 40 \%, 50 \%$, and $60 \%$ of L. leucocephala, reporting a reduction of $63 \%$ in $\mathrm{CH}_{4}$ production when the level of incorporation of the legume was $60 \%$ compared to the control treatment ( $0 \%$ L. leucocephala). Rira et al [10] included 75\% and $100 \%$ of L. leucocephala in an in vitro system and found reductions of $27.0 \%$ and $31.5 \%$ in $\mathrm{CH}_{4}$ emissions, while Molina-Botero et al [37] incubated $100 \%$ of L. leucocephala and found a reduction of $31 \%$ in $\mathrm{CH}_{4}$ emissions when expressed as $\mathrm{g} / \mathrm{kg}$ DM. Delgado et al [30] included $27 \%$ of L. leucocephala in sheep rations and observed a reduction of $15.6 \%$ in $\mathrm{CH}_{4}$ emissions (L/kg DMI).

In the experiment hereby described, a reduction of $39.4 \%$ was recorded in $\mathrm{CH}_{4}$ production with $40 \%$ of DM ration of L. leucocephala fed to growing heifers housed in open-circuit respiration chambers. Recent work by Soltan et al [8] included $35 \%$ of $L$. leucocephala in sheep rations and found a reduction in $\mathrm{CH}_{4}$ production of $14.3 \%$ when expressed as $\mathrm{L} / \mathrm{kg}$ of digestible organic matter, this result is lower than that found in the present experiment with $40 \%$ of inclusion of L. leucocephala (32.1\% less $\left.\mathrm{CH}_{4}\right)$. Also, these results differ from results reported by Kennedy and Chamrley [4] who registered a reduction $\left(\mathrm{L} \mathrm{CH}_{4} / \mathrm{kg} \mathrm{DMI}\right)$ in emissions of $13.4 \%$ and $20.5 \%$ when they included $22 \%$ and $44 \%$ of $L$. leucocephala in cattle rations.

A higher reduction in methane production per $\mathrm{kg}$ of DMI was found in the experiment hereby described with $20 \%$ and $40 \%$ incorporation of L. leucocephala (26.7\% and $39.4 \%$ less $\mathrm{CH}_{4} / \mathrm{kg}$ DMI, respectively) and when results were expressed as $\mathrm{L} \mathrm{CH}_{4} / \mathrm{kg}$ DOMI, our results were similar to the values reported by Kennedy and Chamrley [4] with $22 \%$ and $44 \%$ of L. leucocephala in the ration $\left(19.2 \%\right.$ and $28.2 \%$ less $\mathrm{CH}_{4} / \mathrm{kg}$ DOMI). However, our results with $80 \%$ of inclusion of L. leucocepha in the diet differed from that reported by Dias-Moreira et al [34] whoadded $82 \%$ of $L$. leucocephala ( $40 \mathrm{~g} \mathrm{CT} / \mathrm{kg} \mathrm{DM})$ to sheep rations and found a reduction of $26 \%$ in rumen methane production. This could be associated with the CT concentrations on the diet. Grainger et al [33] included 1.46\% CTs per kg dry matter and found a reduction of $22.3 \%$, and in our present work the inclusion of $1.64 \% \mathrm{CT}$ per $\mathrm{kg}$ of ration DM ( $80 \%$ of L. leucocephala), induced a reduction in methane production of $61.3 \%$.

Min et al [31] found that the inclusion of $2 \%$ of $\mathrm{CT}$ as DM exerted a reduction of $31 \%$ in ruminal $\mathrm{CH}_{4}$ production. In several experiments using plants containing CTs, similar reductions in $\mathrm{CH}_{4}$ emissions to those found in the experiment hereby described have been registered. Puchala et al [35] found that goats fed Lespedeza cuneata containing $153 \mathrm{~g} \mathrm{CT} / \mathrm{kg}$ DM reduced enteric $\mathrm{CH}_{4}$ emissions by $57.1 \%$. Similar data were reported by Animut et al [38] in goats eating 200, 447, and $613 \mathrm{~g}$ DM of Lespedeza striata and found a reduction in $\mathrm{CH}_{4}$ emissions of $32.8 \%, 47.3 \%$, and $58.4 \%$, respectively.
This lower digestibility $[4,8]$ could reduce $\mathrm{CH}_{4}$ synthesis because the fibrous component on the diet with legume was lower due to their lower amounts of lignified components compared with tropical grasses, so the time of residence in the rumen is shorter [39,40,7]. In this experiment, a reduction in rumen protozoa population was not observed, probably due to the low concentration of CT ( $<20 \mathrm{~g} / \mathrm{kg} \mathrm{DM}$; [41]), however, several workers have mentioned that CT can reduce protozoa population but furthermore, they can also reduce the enzymatic activity of protozoa and bacteria [10].

Rumen $\mathrm{pH}$ and molar proportions of volatile fatty acid Rumen $\mathrm{pH}$ was unaffected by the level of inclusion of L. leucocephala due to the fact that the forages had a high content of cellulose. The increase in the concentration of rumen $\mathrm{NH}_{3}-\mathrm{N}$ is related to the increase in $\mathrm{CP}$ digestibility and it was observed that rumen ammonia concentration in the treatments with inclusion of $L$. leucocephala was above values considered as normal ( 15 to $20 \mathrm{mg} / \mathrm{dL}$ ). This is contrary to that reported by Traiyakun et al [42], who included $0 \%, 25 \%, 50 \%$, and $75 \%$ of $L$. leucocephala in goat rations and found no effect on rumen $\mathrm{NH}_{3}-\mathrm{N}$ concentrations. Osakwe and Steingass [43] observed a reduction in rumen $\mathrm{NH}_{3}-\mathrm{N}$ concentrations as the level of L. leucocephala was increased from $0 \%, 25 \%$, and $50 \%$ of ration dry matter, claiming this was due to the reduction in rumen degradation of $\mathrm{CP}$ [44]. In the present study, rumen concentrations of acetic, propionic and butyric acids ( $\mathrm{mmol} / \mathrm{L}$ ) were unaffected; however, when acetic acid is expressed as a percentage relative to the other VFA, its contribution increased as the level of $L$. leucocephala in the ration was increased. On the contrary, percentage of propionic acid was linearly reduced as L. leucocephala in the ration was increased, and the same trend was observed for the proportion of butyric acid. It was observed that the ratio acetic:propionic acid was increased as the level of $L$. leucocephala in the ration was augmented. These results agree with those reported by Tan et al [36] who under in vitro conditions incorporated $0 \%, 20 \%, 30 \%, 40 \%, 50 \%$, and $60 \% \mathrm{~L}$. leucocephala, and observed a linear increase in the concentration of acetic acid, but a reduction in the proportion of propionic acid and an increase in the acetic:propionic ratio in the rumen. Our results are also supported by Tiemann et al [45], who evaluated the molar proportions of VFA under in vitro conditions when they mixed L. leucocephala with $P$. purpureum and found that $L$. leucocephala resulted in a higher amount of acetic acid but reduced the concentration of propionic acid. Rira et al [10] evaluated in vitro inclusions of $25 \%$, $50 \%, 75 \%$, and $100 \%$ L. leucocephala and they did not find any effect on the molar proportions ( $\mathrm{mol} / 100 \mathrm{~mol}$ ) of acetic and propionic acids. However, when they included $44 \%$ of $\mathrm{L}$. leucocephala in Texel sheep rations, a reduction of $5.6 \%$ in acetic acid and an increase of $22.8 \%$ in the concentration of propionic acid were found. The results of other studies also differ; Soltan 
et al [44] found that at levels of $50 \%$ of L. leucocephala, total concentration of VFA was increased by $17.3 \%$, contrary to that found in the present experiment where no effect was observed on any of the main VFA in the rumen. Authors such as Tiemann et al [45] pointed out that the source of CT is an important factor which determines the effect on ruminal fermentation, however, the concentrations, molecular weight and the chemical structure of CTs are all important factors which determine their effect on the molar proportions of VFA $[45,46]$. It is still possible that the low concentrations of CT (1.64\% CT/kg DMI) at the maximum level ( $80 \%$ of ration DM as L. leucocephala) of incorporation of the legume, had no effect in the concentrations of VFA when expressed as $\mathrm{mmol} / \mathrm{L}$.

\section{Rumen protozoa population}

The precise mechanism whereby CTs reduce $\mathrm{CH}_{4}$ production is still uncertain, however CTs have the capacity to reduce protozoa [46] and methanogenic archaea populations [7]. CT could also reduce $\mathrm{CH}_{4}$ production by means of indirect mechanisms as the reduction in digestibility of dietary components [42] by forming chemical complexes with carbohydrates and proteins as it was found in this experiment in which a reduction in OMD was recorded as the level of incorporation of $L$. leucocephala was increased as well as by linearly reduced NDFD and ADFD (Table 2).

Several studies indicate that CTs of tropical trees or legumes have the capacity of reducing rumen protozoa $[46,47,36,35]$, and bacteria [7] populations. It is known that protozoa populations are responsible for $37 \%$ of $\mathrm{CH}_{4}$ emissions [48] and they can degrade up to $50 \%$ of the fibrous fraction of feedstuffs $[49,50]$. Working with protozoa-free animals, Yañez-Ruiz et al [48] found a reduction in $\mathrm{CH}_{4}$ emissions. In the experiment hereby described, no effect was detected of CT contained in L. leucocephala on rumen populations of holotrich and entodiniomorph, similar data was reported by Sliwinski et al [51] who fed $0.5 \%$ and $1.0 \% \mathrm{CT} / \mathrm{kg} \mathrm{DM}$ and did not find any effect on these populations in the rumen. These findings are similar to those reported by Rira et al [10] who incorporated $44 \%$ of L. leucocephala as a source of CT and did not find any effect on rumen protozoa population. However, under in vitro conditions, Tan et al [26] included 20\%, 30\%, 40\%, 50\%, and 60\% of $L$. leucocephala and found a linear reduction in total and ciliate protozoa. Also, Galindo et al [47] found that at inclusions of $30 \%$ of $L$. leucocephala, rumen protozoa population was reduced by $39.4 \%$. Puchala et al [35] supplemented goats with Lespedeza cuneata (20\% CT/kg DM) and observed a reduction of $65 \%$ in ciliate protozoa compared to the treatment when only grass was fed. These findings suggest that small doses of CT in L. leucocephala (1.64\% CT/kg DMI; 80\% of $L$. leucocephala in ration $\mathrm{DM}$ ) have no effect on rumen protozoa population.

\section{CONCLUSION}

As a source of CT, the tropical legume tree L. leucocephala has the capacity to reduce enteric methane emissions in cattle without affecting DM and OM intake, while providing a considerably improved intake of rumen fermentable $\mathrm{N}$ for the growth of the microbial population. Inclusion of $80 \%$ of $L$. leucocephala in the diet of heifers fed low-quality tropical forages has the capacity to reduce up to $61.3 \%$ the methane emission without affecting DMI and OMI, protozoa population and the molar concentration of VFA's.

\section{CONFLICT OF INTEREST}

We certify that there is no conflict of interest with any financial organization regarding the material discussed in the manuscript.

\section{ACKNOWLEDGMENTS}

The senior author is grateful to CONACYT-Mexico for granting a $\mathrm{PhD}$ scholarship at the Faculty of Veterinary Medicine and Animal Science, University of Yucatan, Merida, Mexico.

\section{REFERENCES}

1. Moss AR, Jouany JP, Newbold J. Methane production by ruminants: its contribution to global warming. INR EDP Sciences Ann Zootech 2000;49:231-53.

2. Gerber PJ, Steinfeld H, Herderson B, et al. Tackling climate change through livestock- a global assessment of emission and mitigation opportunities. Rome, Italy: Food and Agriculture Organization (FAO); 2013. 206 p.

3. Johnson KA, Johnson DE. Methane emissions from cattle. J Anim Sci 1995;73:2483-92.

4. Kennedy PM, Charmley E. Methane yields from Brahman cattle fed tropical grasses and legumes. Anim Prod Sci 2012; 52:225-39.

5. Chaokaur A, Nishida T, Phaowphaisal I, Sommart K. Effects of feeding level on methane emissions and energy utilization of Brahman cattle in the tropics. Agric Ecosyst Environ 2014; 199:225-30.

6. Archimède $\mathrm{H}$, Eugène $\mathrm{M}$, Marie-Magdeleine $\mathrm{C}$, et al. Comparison of methane production between $\mathrm{C} 3$ and $\mathrm{C} 4$ grasses and Legumes. Anim Feed Sci Technol 2011;166-167:59-64.

7. Min BR, Solaiman S, Shange R, Eun JS. Gastrointestinal bacterial and methanogenic archaea diversity dynamics associated with condensed tannin-containing pine bark diet in goats using 16S rDNA amplicon pyrosequencing. Int J Microbiol 2014;2014:141909.

8. Soltan YA, Morsy AS, Sallam SMA, et al. Contribution of condensed tannins and mimosine to the methane mitigation 
caused by feeding Leucaena leucocephala. Arch Anim Nutr 2013;67:169-84.

9. Gunun P, Wanapat M, Gunun N, et al. Effects of condensed tannins in mao (Antidesma thwaitesianum Muell. Arg.) seed meal on rumen fermentation chracteristics and nitrogen utilization in goats. Asian-Australas J Anim Sci 2016;29:1111-9.

10. Rira M, Morgavi DP, Archimède $\mathrm{H}$, et al. Potential of tanninrich plants for modulating ruminal microbes and ruminal fermentation in sheep. J Anim Sci 2015;93:334-47.

11. Wahyuni S, Yulianti ES, Komara W, et al. The performance of Ongole cattle offered either grass, sundried Leucaena leucocephala or varying proportions of each. Trop Anim Prod 1982; 7:275-83.

12. Bruinenberg MH, van der Honing Y, Agnew RE, et al. Energy metabolism of dairy cows fed on grass. Livest Prod Sci 2002; 75:117-28.

13. Harrison MT, McSweeney C, Tomkins N, Eckard RJ. Improving greenhouse gas emissions intensities of subtropical and tropical beef farming systems using Leucaena leucocephala. Agric Syst 2015;136:138-46.

14. García E. Modifications to the climate classification system of Copen to adapt it to the conditions of the Mexican Republic. Mexico, Mexico: Institute of Geography, National Autonomous University of Mexico; 1981.

15. Cochran WG, Cox GM. Experimental designs. 2nd edition. New York, USA: John Wiley and Sons Inc.; 1968. 661 p.

16. Ramos-Morales E, Arco-Pérez A, Martín-García AI, et al. Use of stomach tubing as an alternative to rumen cannulation to study ruminal fermentation and microbiota in sheep and goats. Anim Feed Sci Technol 2014;198:57-66.

17. Hales KE, Brown-Brandl TM, Freetly HC. Effects of decreased dietary roughage concentration on energy metabolism and nutrient balance in finishing beef cattle. J Anim Sci 2014;92: 264-71.

18. Bhatta R, Enishi O, Yabumoto Y, et al. Methane reduction and energy partitioning in goats fed two concentrations of tannin from Mimosa Spp. J Agric Sci (Camb) 2013;151:11928.

19. Ryan JP. Determination of volatile fatty acids and some related compounds in ovine rumen fluid, urine and blood plasma by gas-liquid chromatography. Anal Biochem 1980;108:374-84.

20.Pinares-Patino CS, Waghorn G. Technical manual on respiration chamber designs. Wellington, New Zealand: Ministry of Agriculture and Forestry; 2012.

21. Gardiner TD, Coleman MD, Innocenti F, et al. Determination of the absolute accuracy of UK chamber facilities used in measuring methane emissions from livestock. Measurement 2015; 66:272-9.

22. Rosales M. Use of fodder trees for the control of ruminal protozoa. Livest Res Rural Dev 1989;1:79-85.

23.FAO. Determination of cell concentrations using haemocytometer according to Fuchs Rosenthal and Burker [Internet].
Gent, Belgium: FAO, 2003 [April 16, 2016]. Available from: http://www.fao.org/DOCREP/003/W3732E/w3732e0b.htm

24. Ogimoto K, Imai S. Atlas of rumen microbiology. Tokyo, Japan: Japan Scientific Societies Press; 1981. 223 p.

25.AOAC. Official methods of analysis. Association of Official Analytical Chemists. 15th Edition. Washington DC, USA: AOAC International; $1980.70 \mathrm{p}$.

26. Van Soest PJ, Robertson JB, Lewis BA. Methods for dietary fiber, neutral detergent fiber and non-starch polysaccharides in relation to animal nutrition. J Dairy Sci 1991;74:3583-97.

27.Makkar HPS. Quantification of tannins in tree and shrub foliage: a laboratory analysis. Dordrecht, The Netherlands: Kluwer Amademic Publisher; 2003.

28.SAS. Institute Inc., SAS/STAT. Software, Ver. 9.00. Cary, NC, USA: SAS Inc.; 2006.

29. Kumar R, Singh M. Tannins: their adverse role in ruminant nutrition. J Agric Food Chem 1984;32:447-53.

30. Delgado DC, Galindo J, Ibett JCO, Dominguez M, Dorta N. Supplementation with foliage of $L$. leucocephala. Its effect on the apparent digestibility of nutrients and production of methane in sheep. Rev Cub Cienc Agric 2013;47:267-71.

31.Min BR, Pinchak WE, Anderson RC, Fulford JD, Puchala R. Effects of condensed tannins supplementation level on weight gain and in vitro and in vivo bloat precursors in steers grazing winter wheat. J Anim Sci 2006;84:2546-54.

32. Beauchemin KA, McGinn SM, Martinez TF, McAllister TA. Use of condensed tannin extract from quebracho trees to reduce methane emissions from cattle. J Anim Sci 2007;85: 1990-6.

33. Grainger C, Clarke T, Auldist MJ, et al. Potential use of Acacia mearnsii condensed tannins to reduce methane emissions and nitrogen excretion from grazing dairy cows. Canadian J Anim Sci 2009;89:241-51.

34.Dias-Moreira G, Tavares-Lima P de M, Oliveira-Borge B, et al. Tropical tanniniferous legumes used as an option to mitigate sheep enteric methane emission. Trop Anim Health Prod 2013; 45:879-82.

35. Puchala R, Animut G, Patra AK, et al. Methane emissions by goats consuming Sericea lespedeza at different feeding frequencies. Anim Feed Sci Technol 2012;175:76-84.

36. Tan HY, Sieo CC, Abdullah N, et al. Effects of condensed tannins from Leucaena on methane production, rumen fermentation and populations of methanogens and protozoa in vitro. Anim Feed Sci Technol 2011;169:185-93.

37. Molina-Botero IC, Cantet JM, Montoya S, Correa-Londoño GA, Barahona-Rosales R. In vitro methane production from two tropical grasses alone or in combination with Leucaena leucocephala or Gliricidia sepium. Ces Med Vet Zootec 2013; $8: 31$.

38. Animut G, Puchala R, Goetsch AL, et al. Methane emission by goats consuming diets with different levels of condensed tannins from lespedeza. Anim Feed Sci Technol 2008;144:212- 
27.

39.Pinares-Patino CS, Ulyatt MJ, Lassey KR, Barry TN, Holmes CW. Rumen function and digestion parameters associated with differences between sheep in methane emissions when fed chaffed lucerne hay. J Agric Sci 2003;140:205-14.

40. Assoumaya C, Sauvant D, Archimède H. Comparative study of ingestion and digestion of tropical and temperate forage. INRA Prod Anim 2007;20:383-92.

41. Jayanegara A, Leiber F, Kreuzer M. Meta-analysis of the relationship between dietary tannin level and methane formation in ruminants from in vivo and in vitro experiments. J Anim Physiol Anim Nutr 2012;96:365-75.

42. Traiyakun S, Harakord W, Yuangklang C, Paengkoum P. Leucaena leucocephala meal as replacement to soybean meal in growing goat diets. J Agric Sci Technol 2011;1:1150-4.

43. Osakwe II, Steingass H. Ruminal fermentation and nutrient digestion in West African Dwarf (WAD) sheep fed Leucaena leucocephala supplemental diets. Agroforest Syst 2006;67:12933.

44. Soltan YA, Morsy AS, Sallam SMA, Louvandini H, Abdalla AL. Comparative in vitro evaluation of forage legumes (prosopis, acacia, atriplex, and leucaena) on ruminal fermentation and methanogenesis. J Anim Feed Sci 2012;21:759-72.
45. Tiemann TT, Lascano CE, Wettstein HR, et al. Effect of the tropical tannin-rich shrub legumes Calliandra calothyrsus and Flemingia macrophylla on methane emission and nitrogen and energy balance in growing lambs. Animal 2008;2:790-9.

46. Finlay BJ, Esteban G, Clarke KJ, et al. Some rumen ciliates have endosymbiotic methanogens. FEMS Microbiol Lett 1994;117: 157-61.

47.Galindo J, González N, Delgado D, et al. Modulating effect of Leucaena leucocephala on the ruminal microbiota. Zootec Trop 2008;26:249-52.

48. Yañez-Ruiz DR, Hart KJ, Martin-Garcia IA, Ramos S, Newbold CJ. Diet composition at weaning affects the rumen microbial population and methane emissions by lambs. Aust J Exp Agric 2008;48:186-8.

49. Coleman GS. The distribution of carboxymethylcellulase between fractions taken from the rumen of sheep containing no protozoa or one of five different protozoal populations. J Agric Sci 1986;106:121-7.

50. Demeyer DL. Rumen microbes and digestion of plant cell walls. Agric Environ 1981;6:295-337.

51.Sliwinski BJ, Carla RS, Machmuller A, Kreuze M. Efficacy of plant extracts rich in secondary constituents to modify rumen fermentation. Anim Feed Sci Technol 2002;101:101-14. 